Published in final edited form as:

Curr Protoc Pharmacol. 2012 September ; CHAPTER: Unit5.61. doi:10.1002/0471141755.ph0561s58.

\title{
Overview of Animal Models of Obesity
}

\author{
Thomas A. Lutz ${ }^{1}$ and Stephen C. Woods ${ }^{2}$ \\ Thomas A. Lutz: tomlutz@vetphys.uzh.ch; Stephen C. Woods: woodssc@ucmail.uc.edu \\ ${ }^{1}$ Vetsuisse Faculty University of Zurich, Institute of Veterinary Physiology, Zurich Center of \\ Integrative Human Physiology, Winterthurerstrasse 260, 8057 Zurich, Switzerland, phone +4144 \\ 6358808 , fax +41446358932 \\ ${ }^{2}$ Program in Neuroscience, University of Cincinnati, Department of Psychiatry and Behavioral \\ Neuroscience, College of Medicine, University of Cincinnati, Obesity Research Center, \\ Department of Psychiatry, University of Cincinnati, 2170 E. Galbraith Road, Cincinnati, OH 45237
}

\begin{abstract}
This is a review of animal models of obesity currently used in research. We have focused upon more commonly utilized models since there are far too many newly created models to consider, especially those caused by selective molecular genetic approaches modifying one or more genes in specific populations of cells. Further, we will not discuss the generation and use of inducible transgenic animals (induced knock-out or knock-in) even though they often bear significant advantages compared to traditional transgenic animals; influences of the genetic modification during the development of the animals can be minimized. The number of these animal models is simply too large to be covered in this chapter.
\end{abstract}

\section{INTRODUCTION}

The incidence of obesity continues to climb worldwide, making it imperative that animal models sharing characteristics of human obesity and its co-morbidities be developed in the quest for novel preventions and/or treatments. While there is a clear and well-documented genetic component for the tendency to become obese, most instances of human obesity are nonetheless considered to be polygenic, resulting from the integrated activity of numerous genes each of which carries only a small risk factor on its own. Animal models of obesity can therefore be partitioned into different categories, the major ones being based on mutations or manipulations of one or a few individual genes vs. those in genetically intact animals exposed to obesigenic environments such as being maintained on high-fat diets.

While it is beyond the scope of this short review to delve into the causes of obesity, many excellent reviews exist (Kaiyala and Schwartz, 2011; Leibel, 2008; Schwartz et al., 2003; Woods, 2009). Considerable research is based on the premise that a primary causal factor lies in the interaction of the brain with peripheral tissues such as the gut, the liver, the endocrine pancreas, adipose tissue and others. This is typically manifest as dysfunctional eating, energy metabolism and/or autonomic activity. Note that this could occur via abnormal signaling by peripheral organs to the brain (e.g., indicating that insufficient fat is present, thus triggering increased food intake and consequent increased body fat) and/or by abnormal signaling from the brain to other organs (e.g., reduced sympathetic and increased parasympathetic activity to the endocrine pancreas and liver after certain brain lesions).

Because food intake has high face validity when considering possible factors influencing body adiposity, most characterizations of animal models include assessments of intake as well as of body fat, plasma leptin, insulin and glucose, and other related parameters. It is therefore important to understand the basics of the controls of food intake and how they 
might relate to obesity. It is generally accepted that factors that influence food intake and consequently body fat can be conceptualized as those that influence when individuals start eating and those that influence when eating, once begun, will end; i.e., factors that stimulate appetite or eating per se and those that stimulate fullness or satiation. Except in rare circumstances, eating is initiated by factors such as habit, time of day, the social situation, food availability, and so on (Woods, 1991; Woods, 2009). The amount eaten (i.e., meal size), on the other hand, is determined by satiation factors generated by the gastrointestinal system interacting with ingested food. The best known satiation factor is the intestinal peptide, cholecystokinin (CCK). Satiation factors interact in the brain with signals emanating from adipose tissue and other organs indicating how lean or fat the individual is. These adiposity signals, such as leptin and insulin, interact with receptors in the hypothalamus and have potent effects on food intake, energy expenditure and the level of stored fat. The majority of animal models commonly used to investigate causes and treatments for obesity therefore have altered activity in brain circuits integrating satiation and adiposity signals (Woods, 1991; Woods, 2009).

\section{ANIMAL MODELS OF OBESITY}

Admittedly, reviews of animal models of obesity are always somewhat subjective for the choice of models included. The critera for choosing the animals models of this chapter were:

- The model has been used frequently in obesity research.

- The model has a historic perspective, e.g. because they enabled identification of major areas in the brain involved in the control of eating and body weight.

- The model has been influential for the subsequent generation of more specific animal models, e.g. specific knockout or transgenic (potentially inducible) models based on the discovery of the leptin pathway.

- The models cover the most important different types of models like genetic or nongenetic models.

- Within the genetic models, monogenic and polygenic models are represented.

- Within monogenic models, two main categories are represented; in other words, we included monogenic models linked to the pathway of an adiposity signal (undoubtedly, the leptin pathway was the most critical to trigger an enormous research activity in recent years) and of a satiation signal like CCK.

Hence, we have organized the models in a schema that we believe is useful (Table 1). The major criteria used to choose these animal models included:

- The animal model shows a distinct phenotype of obesity, hyperphagia or change in energy metabolism.

- The animal model may also show some of the most frequent comorbidities of obesity, like hyperglycemia, insulin resistance or diabetes-like syndromes.

Because it is the best worked out, we start with the monogenic mutations involving the leptin pathway (Schwartz et al., 2000). Spontaneous mutations leading to marked obesity had been described long before the underlying causes (e.g., defects in the leptin gene or the leptin receptor gene) had been discovered. Discoveries in this pathway led to the subsequent generation of a large number of engineered mutants. Another prominent animal model of obesity that resulted from a spontaneous mutation is the Otsuka Long Evans Tokushima Fatty (OLETF) rat which lacks functional receptors for the satiating hormone CCK. Dietinduced models of obesity (DIO) are often used to study polygenic causes of obesity. DIO animals are believed to mimic better the state of common obesity in humans than most of 
the genetically modified models and may be the best choice for testing prospective therapeutics. Finally, we summarize models of surgically or chemically-induced and seasonal models of obesity. Surgically induced obesity has lost much of its importance since the introduction of genetically modified animals which allow the more specific ablation of neurons in defined parts of the brain.

Most animal models of obesity are small rodents (rats or mice), but it should be mentioned that most mammals, when maintained in small enclosures with free food (as in many zoos in the past), develop obesity. The most commonly used animal models of obesity are probably the leptin-deficient ob/ob mouse, the leptin receptor deficient $\mathrm{db} / \mathrm{db}$ mouse, its rat counterparts like the Zucker rat, the MC4 receptor deficient animals and models of diet induced obesity. The choice of model for a particular experiment depends upon the goal of the study. For example, DIO animals are believed to mimic better the state of common obesity in humans than most of the genetically modified models and may be the best choice for testing prospective therapeutics. Transgenic models or models with spontaneous mutations may be used in the evaluation of a prospective therapeutic to determine whether it engages a specific target or pathway in vivo. The transgenic models and models with spontaneous mutations may also be used to explore the role of specific molecular targets and pathways in the physiology of food intake and their potential role in obesity.

\section{MONOGENIC MODELS}

Several models have been described in which a single gene is lacking or dysfunctional in the entire animal.

\section{MONOGENIC MUTATIONS IN THE LEPTIN PATHWAY}

\section{Leptin and its receptor}

Animals with a defect in the leptin-signaling pathway in the hypothalamus of the brain develop a morbidly obese phenotype. The models include animals that lack leptin production and/or that are insensitive to leptin due to leptin receptor mutations or extreme leptin resistance. Mutations are spontaneous (e.g., Lep ${ }^{\mathrm{ob}} / \mathrm{Lep}^{\mathrm{ob}}$ mouse; Lep ${ }^{\mathrm{db}} / \mathrm{Lep}^{\mathrm{db}}$ mouse) or genetically engineered. Animals with mutations that lie downstream of the leptin-sensing neurons in the hypothalamus are also included.

ob/ob mouse (Lep ${ }^{\text {ob}} /$ Lep $^{\text {ob }}$ mouse, the 'obese' mouse)-A spontaneous mutation leading to the markedly obese phenotype in the Lep ${ }^{\mathrm{ob}} / \mathrm{Lep}^{\mathrm{ob}}$ mouse has been recognized since the 1950s (Coleman, 1978; Mayer et al., 1951). However, it was not until the discovery in 1994 of the underlying mechanisms and characterization of the ob gene product, leptin, that intensive research on the genetics of obesity really increased dramatically (Zhang et al., 1994). Today, the ob gene is one of the most-studied genes in obesity research. A single-base spontaneous mutation of the ob gene prevents the secretion of bioactive leptin because leptin synthesis is terminated prematurely. Leptin is mainly synthesized in white adipocytes and its secretion is directly proportional to the amount of stored triglyceride. Leptin deficiency has also been observed in rare cases of human obesity (O’Rahilly, 2009).

Phenotypically, the lack of leptin leads to marked, early-onset obesity characterized by hyperphagia, reduced energy expenditure and hypothermia; further defects are hypercorticosteronemia, insulin resistance associated with hyperglycemia and hyperinsulinemia, hypothyroidism and growth hormone deficiency leading to a decrease in linear growth. Lep ${ }^{\mathrm{ob}} / \mathrm{Lep}^{\mathrm{ob}}$ mice are infertile. Obesity in Lep ${ }^{\mathrm{ob}} / \mathrm{Lep}^{\mathrm{ob}}$ mice is one of the few forms of obesity that can be treated effectively by the administration of exogenous leptin. 
Leptin normalizes all known phenotypic defects in Lep ${ }^{\mathrm{ob}} / \mathrm{Lep}^{\mathrm{ob}}$ mice including obesity, symptoms of the metabolic syndrome and reproductive function (Bray and York, 1979; Campfield et al., 1995; Coleman, 1978; Friedman, 1998; Halaas et al., 1995; Pelleymounter et al., 1995; Zhang et al., 1994).

$\mathbf{d b} / \mathbf{d b}$ mouse (the 'diabetic' mouse)—The leptin receptor-deficient " $\mathrm{db} / \mathrm{db}$ " mouse, also called the $\operatorname{Lep}^{\mathrm{db}} / \mathrm{Lep}^{\mathrm{db}}$ mouse, is phenotypically similar to the $\mathrm{Lep}^{\mathrm{ob}} / \mathrm{Lep}^{\mathrm{ob}}$ mouse and was so-named because there is more marked hyperglycemia on some background strains than occurs in the $\mathrm{Lep}^{\mathrm{ob}} / \mathrm{Lep}^{\mathrm{ob}}$ mouse. Lep ${ }^{\mathrm{db}} / \mathrm{Lep}^{\mathrm{db}}$ mice are also characterized by hyperphagia and reduced energy expenditure leading to marked early-onset obesity; they are hypothermic, have decreased linear growth due to growth hormone deficiency, and they are infertile (Chua et al., 1996; Coleman, 1978; Halaas et al., 1995). The major difference from the $\mathrm{Lep}^{\mathrm{ob}} / \mathrm{Lep}^{\mathrm{ob}}$ mouse is the marked resistance to leptin because the $\mathrm{Lep}^{\mathrm{db}} / \mathrm{Lep}^{\mathrm{db}}$ mouse has a (spontaneously) mutated leptin receptor. These mice also suffer from morbid obesity but their leptin levels are markedly elevated. Lep ${ }^{\mathrm{db}} / \mathrm{Lep}^{\mathrm{db}}$ mice are insulin resistant and develop diabetes; $\mathrm{Lep}^{\mathrm{db}} / \mathrm{Lep}^{\mathrm{db}}$ mice have often been used to study type II diabetes-like syndromes, but Lep ${ }^{\mathrm{db}} / \mathrm{Lep}^{\mathrm{db}}$ mice do not develop the full phenotype of type II diabetes; among other differences, they lack pancreatic amyloid deposition. Analogous to the ob gene mutation, the mutation of the leptin receptor gene is also found in some human families; however, the mutation is very rare.

$\mathbf{s} / \mathbf{s}$ mouse-The s/s mouse is a more specific, genetically engineered animal model of leptin receptor deficiency (Bates et al., 2005; Bates et al., 2003). In contrast to the defect in the Lep ${ }^{\mathrm{db}} / \mathrm{Lep}^{\mathrm{db}}$ mouse which leads to generalized leptin receptor dysfunction, the s/s mouse carries a mutation that specifically disrupts the transcription factor STAT3, which is a key component of the signaling pathway of the long form of the leptin receptor and that mediates leptin's effects on energy homeostasis. The amino acid tyrosine at position Tyr 1138 is crucial for the activation of this pathway by leptin. The specific replacement of the gene encoding the leptin receptor in mice with an allele coding for a serine residue (Ser 1138 instead of Tyr 1138) disrupts the STAT3 signal. Homozygous (s/s) mice are hyperphagic and obese, but they are fertile, have normal body length and are less hyperglycemic compared to the Lep ${ }^{\mathrm{db}} /$ Lep $^{\mathrm{db}}$ mouse. STAT3 mediates leptin's effects on body energy homeostasis via melanocortin signaling, whereas other signaling pathways are necessary for the control of fertility, body growth and glucose homeostasis. Eventually, however, s/s mice develop severe insulin resistance similar to that in $\mathrm{Lep}^{\mathrm{db}} / \mathrm{Lep}^{\mathrm{db}}$ mice, particularly in the liver.

Leptin receptor-deficient rats; Zucker rat, ZDF rat, Koletsky rat-Analogous to the Lep ${ }^{\mathrm{db}} /$ Lep $^{\mathrm{db}}$ mouse, several rat models of leptin-resistant obesity have mutations in the leptin receptor. The obese Zucker (fa/fa or 'fatty' rat) and the Koletsky rat carry mutated forms of the extracellular domain of the leptin receptor. They develop a similar phenotype of hyperphagia and reduced energy expenditure, leading to morbid obesity (Bray, 1977; Bray and York, 1979). These rats have impaired glucose tolerance, a growth deficit possibly related to a lower activity of the GH/IGF-1 axis and hypothyroidism. Fertility is reduced. Koletsky rats have a nonsense and null mutation that leads to undetectable levels of leptinreceptor mRNA expression (Chua et al., 1996; Crouse et al., 1998; da Silva et al., 1998; Friedman, 1997; Takaya et al., 1996; Wu-Peng et al., 1997). In contrast, the fa/fa mutation of Zucker fatty rats is associated with a processing defect of the leptin receptor; the receptor is generated but retained intracellularly, leading to reduced numbers of leptin receptors on the cell surface. This is associated with decreased leptin binding and signal transduction. Koletsky rats are more hypertensive and have a more severe phenotype of insulin resistance than Zucker fatty rats. 
Zucker Diabetic Fatty (ZDF) rats were derived from a substrain of obese Zucker fatty rats that displayed early dysregulation of glucose metabolism. ZDF rats develop early diabetes when presented with a high-fat diet, and part of their propensity to develop early diabetes may be related to an altered expression of the glucose transporter GLUT4 in skeletal muscle (Zierath et al., 1998).

Wistar Kyoto fatty rat (WDF rat) —A related rat model was created by crossing Zucker (fa/fa) rats with Wistar-Kyoto (WKY) rats. Similar to the Zucker (fa/fa) rat, the Wistar Kyoto fatty (WDF) rat develops obesity and co-morbidities like insulin resistance, hyperinsulinemia and hyperlipidemia. Male Wistar Kyoto fatty rats develop early hyperglycemia and glucosuria. Insulin resistance is associated with reduced brain and peripheral (liver) insulin binding (Figlewicz et al., 1986; Ikeda et al., 1981).

\section{Obesity models with a deficit downstream of the brain leptin receptor}

POMC knockout mouse-Proopiomelanocortin (POMC) expressing neurons in the hypothalamic arcuate nucleus are direct targets of leptin. POMC is the precursor of several biologically active peptides including a-melanocyte-stimulating hormone (aMSH). In the brain, aMSH is a potent anorexigenic neuropeptide that reduces eating and increases energy expenditure by activating melanocortin (MC) 3 and 4 receptors in the paraventricular nucleus of the hypothalamus and elsewhere.

Transgenic mice lacking POMC (POMC ${ }^{-/}$) and consequently all POMC-derived peptides overeat and develop marked obesity that is exaggerated on a high-fat diet (Challis et al., 2004; Yaswen et al., 1999). Heterozygous mutants develop an intermediate phenotype, implying that both copies of a functional POMC gene are necessary to maintain normal energy homeostasis. Although treatment with leptin is ineffective, the obesity in $\mathrm{POMC}^{-/-}$ mice can be markedly reduced when these mice are treated with aMSH or other agonists of the MC4 receptor, such as MT II. POMC deficiency has also been reported in rare cases of human obesity (O’Rahilly, 2009).

POMC/AgRP knockout mice-Agouti related protein (AgRP) is co-expressed with neuropeptide Y (NPY) in a different population of arcuate nucleus neurons than those that express POMC. AgRP increases eating by acting as an antagonist at the MC4 receptor. Recently, mice with a double knockout for POMC and AgRP were created (Corander et al., 2011). Phenotypically and in terms of their hyperphagia and development of obesity, they were similar to the homozygous POMC ${ }^{-1-}$ knockout mouse. Because aMSH but not AgRP restored the defects in the control of eating and body weight, AgRP on its own seemed to be ineffective; AgRP is therefore considered as an antagonist but not an inverse agonist at the critical melanocortin receptors at physiological concentrations.

MC4R knockout models-aMSH and AgRP influence energy homeostasis via MC receptors. The MC4 receptor subtype in particular is involved in the control of food intake. Specific inactivation of the MC4 receptor by a targeted knockout produces hyperphagia and morbid obesity (Huszar et al., 1997). $\mathrm{MC}^{-/-}$mice are also hyperinsulinemic,

hyperglycemic and hyperleptinemic. In contrast to many other obesity models, $\mathrm{MC}^{-/-}$mice do not have elevated circulating corticosterone levels. $\mathrm{MC}^{-/-}$mice do not respond to leptin, AgRP or aMSH. Similar mutations of the MC4 receptor are often stated to be the most frequent genetic cause of obesity in humans.

An MC4 knockout rat has recently been described (Mul et al., 2011). While it has many characteristics in common with MC4 KO mice (such as increased body weight, food intake and body length, and lower spontaneous activity), there are some noteworthy differences. In 
particular, while the $\mathrm{MC}^{-/-}$mouse has increased expression of NPY but not of POMC in parts of the hypothalamus, the adult MC4 knockout rat has unchanged NPY levels but increased POMC expression.

MC3R knockout mouse-Targeted inactivation of another MC receptor subtype, the MC3 receptor, also produces an obese phenotype (Butler et al., 2000). This syndrome is characterized by a comparably mild increase in total body weight but a marked, late increase in fat accumulation; i.e., MC3 knockout mice have relative adiposity. Fat oxidation in these mice is reduced, especially on a high-fat diet. The mice exhibit hyperleptinemia and relatively mild hyperinsulinemia. Physical activity in cages equipped with running wheels is reduced.

MC4/MC3 receptor knockout mouse-A double knockout of the MC3 and MC4 receptors results in mice that are heavier than the single knockouts (Chen et al., 2000). The MC agonist MTII decreases eating much less in MC3 or MC4 receptor knockout mice than in wildtype controls, but only the double knockouts are completely unresponsive to MTII. These findings suggest that at least in respect to eating, MC4 and MC3-receptor mediated actions are complementary.

Ectopic agouti expression in mice-The agouti gene was cloned in 1992 and was the first obesity gene to be characterized at the molecular level. In wildtype mice, the gene is transiently expressed in hair follicles where it leads to the production of red or yellow pigments and inhibits the production of black or brown pigments in melanocytes by antagonizing $\mathrm{MC} 1$ receptors. Mice with a spontaneous ectopic agouti gene mutation are yellow ('yellow mice').

Several agouti mutations have been described (Michaud et al., 1994). The lethal yellow (Ay) mutation is one of five dominant agouti mutations leading to ectopic agouti expression. Homozygous expression of the spontaneous mutation is lethal and mice typically die before implantation. Heterozygotes are viable, and in addition to their yellow hair color, the mice usually develop obesity within the first few months of life. The obesity results from the ectopic expression of the agouti gene product, especially in the hypothalamus, where, like $\mathrm{AgRP}$, it functionally antagonizes a-MSH at MC3 and MC4 receptors. Lean body mass is slightly increased and adipose tissue mass is increased due to fat cell hypertrophy. In association with the obesity, the mice are prone to developing type II diabetes and are hyperleptinemic. The mice are infertile. Engineered transgenic mice that ubiquitously express agouti have a similar phenotype, arguing for a causal effect of the ectopic agouti expression.

The viable agouti $A^{v y /-}$ mouse also has a mottled yellow pigmentation of the hair. $\mathrm{A}^{\mathrm{vy} /-}$ mice are obese and slightly larger than their respective controls. The mice are hyperinsulinemic, hyperleptinemic and hyperglycemic, as well as insulin resistant and leptin resistant (Klebig et al., 1995; Yen et al., 1994). Interestingly, both homozygous ( $\mathrm{A}^{\mathrm{vy}} / \mathrm{A}^{\mathrm{vy}}$ )

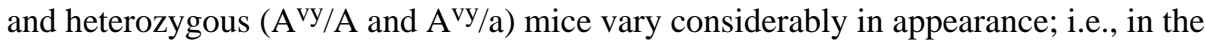
extent of the yellow fur color. The degree of obesity is correlated with the extent of the yellow fur coloration. In addition to the strong influence by the agouti-locus genotype and the genetic background of the dam, epigenetics provides a likely explanation for these differences (Morgan et al., 1999; Wolff et al., 1998).

AgRP overexpression-Agrt (also known as Art or the Agrp gene) shares sequence homology with the agouti gene. Its gene product, agouti-related protein or AgRP, is considered the natural antagonist to a-MSH at MC3 and MC4 receptors in the hypothalamus. Similar to the mice with ectopic agouti expression, transgenic mice 
overexpressing $\mathrm{AgRP}$ are obese and develop hyperinsulinemia with late-onset hyperglycemia (Graham et al., 1997). This eventually results in hyperplastic pancreatic islets.

Carboxypeptidase E (CPE) mutation- $\mathrm{CPE}$ is an enzyme involved in the posttranslational processing of many prohormones into active neuropeptides. For example, in the periphery-cell, CPE helps covert pro-insulin to insulin, and in the central nervous system CPE helps cleave the POMC molecule. Specific point mutations lead to the inactivation of CPE [Cpe(fat)] and a disruption of processing and secretion of POMC and its products including a-MSH. The latter is most likely responsible for the development of obesity in animals with disrupted CPE due to a shifted balance between a-MSH and AgRP activity at MC3 and MC4 receptors. Homozygous mice develop late-onset marked obesity and are infertile (Bures et al., 2001; Naggert et al., 1995).

\section{OTHER MONOGENIC MODELS}

\section{Otsuka Long Evans Tokushima Fatty rat (OLETF)}

Otsuka Long Evans Tokushima Fatty (OLETF) rats are a model of mild obesity (Kawano et al., 1992; Moran, 2008; Moran and Bi, 2006). The name is derived from a colony of Long Evans rats that was selectively bred at the Tokushima Research Institute of Otsuka Pharmaceutical in Japan. The underlying pathology of OLETF rats is that of a CCK-1 receptor knockout; hence, OLETF rats and their lean counterparts (LETO; Long-Evans Tokushima Otsuka) have been used to study physiological CCK functions. Because CCK plays an important role in satiation and because this effect is mediated by CCK-1 receptors, OLETF rats are a valuable animal model to study dysregulated control of eating and obesity. The obesity phenotype is relatively mild.

The hyperphagia and ensuing obesity of OLETF rats relates to a significant increase in the size of meals. This increase results from the lack of the CCK feedback signal which primarily projects to the nucleus of the solitary tract (NTS) in the hindbrain, but may also result from the increased expression of neuropeptide Y (NPY) in the dorsomedial hypothalamic nucleus (DMH). The latter may also explain some apparent species differences between the OLETF rat which becomes obese and the CCK1 receptor knockout mouse which does not on a normal diet (Lo et al., 2010). Interestingly, overeating and an increase in meal size in OLETF rats can be observed in rat pups two days of age. In contrast, obesity models with defective hypothalamic signaling systems often develop overeating and obesity later in life. This difference in the onset of overeating may relate to the maturation of the hindbrain systems of satiation, a process which normally occurs much earlier than that of the hypothalamus; hence, defects in the hindbrain systems which mainly control meal size become obvious at a much earlier age. Consistent with this idea, the overexpression of NPY in the DMH only occurs in the third week of life of the OLETF rats. Hence, at least at this young age, the lack of the incoming CCK signal seems to be sufficient to drive overeating in OLETF rats.

As a result of obesity, OLETF rats develop diabetes; they are hyperglycemic from about 4-5 months of age and develop polyuria and polydipsia. Further, due to the lack of functional CCK1 receptors in the exocrine pancreas, OLETF rats respond less to CCK induced stimulation of pancreatic secretions. While these rats seem unable to compensate for their large meals, they can prevent obesity from occurring if they have access to a running wheel. 


\section{DIET-INDUCED MODELS; POLYGENIC MODELS}

\section{Diet-induced obese (DIO) and diet-resistant (DR) rats}

Outbred Sprague-Dawley rats have been used as a polygenic model of obesity which presumably shares many characteristics with the common form of human obesity. When exposed to a high-energy diet (HE), many Sprague-Dawley rats become obese (DIO) whereas others have a body weight trajectory similar to that of control rats on a low-energy diet; the latter are therefore called diet resistant (DR) (Levin and Dunn-Meynell, 2000; Levin and Dunn-Meynell, 2002; Levin et al., 1997; Levin et al., 1986).

DIO and DR rats have been bred selectively over several generations (Levin et al., 1997; Michel et al., 2004). This has led to a more distinct obese phenotype in DIO compared to DR rats on HE diets. Some strains of DIO rats are now becoming obese without the necessity of being exposed to a HE diet, an effect that is more pronounced in males than in females. Interestingly, the selectively-bred DIO rats are less sensitive to the hypophagic action of leptin by $4-5$ weeks of age, a time when they are still lean and before the body weights of DIO and DR rats start to diverge. Lean DIO rats also have a reduced leptininduced response in several hypothalamic nuclei as assessed by the expression of phosphorylated signal transducer and activator of transcription 3 (the pSTAT3 response). The reduced response to peripheral leptin is not due to a defect at the level of the bloodbrain barrier transport system. The latter system only becomes defective once the DIO rats have developed overt obesity on a low-energy diet or when exposed to a HE diet. Collectively, the data indicate that the hypothalamic leptin signaling system is defective in selectively bred DIO rats before they become overtly obese.

Interestingly, selectively-bred DIO rats can be protected from becoming obese by rearing them in large litters (Patterson et al., 2010), effectively limiting the pups' nutrient supply during the suckling period, and consequently reducing circulating leptin levels and hypothalamic leptin resistance. This reduced body weight persists into adulthood and is associated with a higher sensitivity to leptin in the arcuate nucleus and to the anorectic effect of leptin.

\section{Cafeteria diet-induced obesity}

Rats become obese when offered a varied and palatable diet which mimics the so-called Western diet of humans (cafeteria diet) (Perez et al., 1999; Rogers and Blundell, 1984; Rothwell and Stock, 1979). Cafeteria diet-induced obesity mainly results from hyperphagia that is partly compensated by increased energy expenditure, in particular diet-induced thermogenesis (DIT) due to sympathetic activation of brown fat. Overeating of cafeteria diets is due to increased average meal size as well as increased meal frequency. This contrasts with overeating of palatable diets with no choice of foods, which mainly influences meal size.

\section{High-fat diet-induced obesity}

Even though the contribution of diets with a high-fat content to human adiposity is disputed (Willett and Leibel, 2002), it is clear that the exposure of animals to high-fat (HF) diets often results in the development of obesity. As discussed above, some strains of rats prone to develop DIO exhibit reductions in insulin and leptin sensitivity, but HF diets have similar effects in lean and in DR rats. While the caloric density of HF diets and the ensuing higher intake of total energy contribute to this effect, HF diets rapidly and specifically reduce the central actions of insulin and leptin, most likely due to a post-receptor effect (Banks et al., 2004; Benoit et al., 2009; Clegg et al., 2011; Hariri and Thibault, 2010; Woods et al., 2004). This effect is rapid, occurring after a few days of HF exposure. HF diets seem to directly 
affect the respective intracellular signaling pathways in hypothalamic target neurons with resulting changes in neuropeptide expression (e.g., lack of an insulin effect on POMC expression), but possibly also in other brain areas. Fat composition seems to have a major role in this effect because saturated fat (e.g., palmitic acid) is more deleterious than unsaturated fat.

\section{New Zealand obese mouse}

The New Zealand obese (NZO) mouse is obese and has severe type-2 diabetes (Joost, 2010). A number of genetic susceptibility loci that favor the development of adiposity and hyperglycemia have been identified in NZO mice. In addition to the leptin receptor gene, several genes of transcription factors were identified as potential candidate genes. Some of them are involved in substrate utilization in skeletal muscle and triglyceride storage in adipocytes. Interestingly, orthologs of at least some of these genes have been linked to the human metabolic syndrome.

\section{Age-related obesity in mice (LOO)}

Single housed C57B6 mice develop late onset obesity even when fed a standard chow diet (late-onset obesity; LOO) (Becskei et al., 2009; Becskei et al., 2010). The model resembles common human obesity because it is characterized by a slow, gradual fat accumulation over the individual's life span. LOO mice develop elevated fasting glucose as well as fasting hyperleptinemia and hyperinsulinemia; and they are resistant to the anorectic effect of leptin and hypoglycemic action of insulin.

\section{Age-related obesity in macaques}

Late-onset obesity also occurs in other species, including rhesus macaque monkeys (Macaca mulatta) (Hansen et al., 1995; Schwartz et al., 1993). Obesity develops over a period of about 10-15 years, mainly as a result of (relative) overeating; maintenance of stable adult body weight required a 30-40\% reduction of daily energy intake compared to ad libitum fed monkeys. Macaque obesity is associated with metabolic changes similar to the human metabolic syndrome such as increased intra-abdominal fat, elevated basal insulin, impaired glucose tolerance, and elevated serum triglycerides and cholesterol.

\section{Maternal overfeeding and exposure to high fat diets}

The intrauterine and perinatal environment plays an important role for the life-long control of energy balance. Considerable evidence indicates that early programming can influence metabolism and various aspects of the control of energy intake and expenditure. Feeding pregnant dams a high-fat (HF) diet has a marked effect on their offspring (Levin and Govek, 1998; Sullivan et al., 2010a; Sullivan et al., 2010b; Tamashiro et al., 2009; West et al., 1982).

Offspring of DIO dams are heavier and more obese than offspring of DR animals; and the effect is greater in DIO dams exposed to HF diet. The obesity in the offspring of DIO dams extends into adult life. Similarly, maternal HF feeding in humans leads to offspring that have a markedly increased risk of obesity in adult life; this is paralleled by hyperphagia and a higher preference for fat and sweet foods. The effect of maternal exposure to HF feeding on energy expenditure is less clear. Overall, maternal obesity is associated with an increased obesity in genetically predisposed individuals, and this effect is intensified by dietary factors. 


\section{Early postnatal overfeeding induced obesity; rearing in small litters}

Manipulation of the litter size has been used as a model of early postnatal overnutrition in rats and mice (Faust et al., 1980; Morris et al., 2005; Schmidt et al., 2001). Due to the limited total supply of the dams' milk, adjustment of litter size leads to two levels of early nutrition with pups reared in small litters ingesting more than pups reared in large litters. Early overfeeding leads to adult animals with a significantly higher body weight; this is associated with increased adiposity, early leptin resistance, hyperinsulinemia and glucose intolerance. The effect in the offspring can be potentiated when offered a HF diet after weaning. Importantly, overfeeding rat pups independently of the dam, in order to eliminate differential maternal behavior as an interacting factor, also leads to increased susceptibility to become obese as adults (West et al., 1987).

\section{OTHER GENETICALLY ENGINEERED MUTANTS}

\section{CRF - Transgenic CRF-overexpressing animals}

Corticotrophin releasing factor (CRF), which is synthesized in the hypothalamic paraventricular nucleus, is the primary driver of the hypothalamic-pituitary-adrenal axis (HPAA); activation of CRF neurons results in elevated plasma levels of adrenocorticotropic hormone (ACTH) and corticosterone (GCC). CRF transgenic mice display truncal obesity combined with muscle wasting, thin skin and hair loss. Hence, the mice are a model for the obesity associated with states of hyperadrenocorticism such as Cushing's syndrome (Stenzel-Poore et al., 1992).

\section{Glucose transporter subtype 4 (GLUT4)}

The GLUT4 glucose transporter is the major transporter for insulin-stimulated glucose transport in adipose tissue, skeletal muscle and other tissues. Obesity is often associated with enhanced expression of GLUT4 in adipose tissue suggesting an involvement of GLUT4 in the pathophysiology of obesity. Transgenic mice overexpressing GLUT4 in white or brown adipose tissue develop early onset obesity, probably because of increased insulin-stimulated glucose transport and hence an increased nutrient substrate for adipogenesis. These mice have a marked increase in the number but not size of fat cells; the mice have therefore been used to study fat cell replication and differentiation during the development of obesity(Shepherd et al., 1993).

Perhaps analogously, rats that transgenically overexpress the gluconeogenic enzyme, phosphoenolpyruvate carboxykinase (PEPCK), generate increased glucose and hence increased substrate for synthesizing triglycerides. These animals become hypertriglyceridemic and obese, even on a low-fat diet (Thorburn et al., 1999).

\section{Melanin concentrating hormone ( $\mathrm{MCH})$}

While the physiological role of $\mathrm{MCH}$ in the control of eating and body weight is not clear, central administration of $\mathrm{MCH}$ increases eating in rats and mice. Transgenic mice overexpressing $\mathrm{MCH}$ are hyperphagic and develop obesity late in life when exposed to a HF diet (Ludwig et al., 2001). The ensuing obesity is associated with hyperinsulinemia and insulin resistance.

\section{Beta-3 adrenergic receptor knockout}

$\beta 3$-receptors are mainly expressed in white and brown adipose tissue. Mice deficient in $\beta 3$ receptors are moderately obese (Susulic et al., 1995), and the phenotype is stronger in female than in male mice. Obesity in $\beta 3$-receptor-deficient mice results mainly from decreased activity of the sympathetic nervous system because food intake is similar to that 
in wildtype mice. Total energy expenditure is also unchanged but activation of brown adipose tissue is reduced.

\section{Serotonin 5-HT-2c receptor knockout}

5-hydroxytryptamine (5-HT, serotonin) is a transmitter involved in the control of many essential functions, including eating. Mice which lack functional 5-HT2C receptors develop hyperphagia (Heisler and Tecott, 1999; Tecott et al., 1995) that is obvious from the time of weaning and results in marked body weight gain and adiposity. Energy expenditure is unchanged. Changes in glucose metabolism and insulin sensitivity only occur after the onset of obesity.

\section{Neuropeptide-Y 1 receptor (NPY1R) knockout mouse}

Neuropeptide Y (NPY) is an important hypothalamic neuropeptide that stimulates eating via several receptor subtypes including the NPY1R. Paradoxically, NPY1R-deficient mice develop obesity; obesity occurs independently of an increase in eating and seems to be caused mainly by decreased energy expenditure (Kushi et al., 1998). The latter is associated with a reduced expression of the uncoupling protein type 2 (UCP2) in white fat tissue. These mice allow the study of obesity in the absence of overeating. The effect appears to be more prevalent in females than in males.

\section{NPY2R knockout mice}

Similar to the NPY1R knockout mice, NPY2R-deficient mice also develop paradoxical obesity (Naveilhan et al., 1999). Affected mice are mildly hyperphagic and develop obesity. On normal chow diets, the mice do not develop metabolic abnormalities of glucose or fat metabolism.

\section{Bombesin 3 receptor knockout mice (BRS3 ko)}

Bombesin-like peptides include the amphibian peptide bombesin (BBS), its mammalian analog gastrin-releasing peptide (GRP) and other peptides including neuromedin B (NMB), and all are considered to be satiation factors, reducing the size of ongoing meals much as CCK does. Mice hemizygous for the BRS3 receptor develop late onset obesity due to an increase in eating and a decrease in the metabolic rate (Ohki-Hamazaki et al., 1997). Obesity is associated with disturbed glucose metabolism such as elevated baseline glucose levels, hyperinsulinemia and insulin resistance.

\section{Neuronal insulin receptor knockout mice (NIRKO mice)}

The role of central nervous system insulin receptors has been extensively studied in recent years, and insulin receptors are widely distributed throughout the brain. The physiological role of these receptors has been studied with the use of neuron-specific insulin receptor knockout mice (NIRKO mice). In contrast to systemic insulin receptor knockout mice, NIRKO mice are viable. Consistent with the role of insulin as a negative feedback adiposity signal (Schwartz et al., 2000), NIRKO mice have a moderate increase in food intake and a resulting increase in body weight and adiposity (Bruning et al., 2000). The effect is more pronounced in mice exposed to a HF diet. On a chow diet, only female NIRKO mice develop obesity. Obesity is paralleled by hypertriglyceridemia. Even though only central insulin receptors are deficient, systemic plasma insulin levels are elevated in NIRKO mice.

\section{1beta-HSD-1 overexpression}

The inactive 11-keto form of glucocorticosteroids (cortisone) can be transformed locally in adipose tissueto the bioactive forms cortisol or corticosterone through the enzyme 11betahydroxysteroid dehydrogenase type 1 (11beta HSD-1). Excessive glucocorticosteroids are 
associated with visceral obesity and diabetes even though circulating glucocorticosteroid levels are often normal. Over-expression of 11 beta HSD-1 selectively in adipose tissue results in increased adipose tissue levels of corticosterone and visceral obesity including most features of the metabolic syndrome (Man et al., 2011; Paterson et al., 2004); the effect is more pronounced when mice are exposed to a high-fat diet. Fat-specific 11beta HSD-1 transgenic mice eat more than wildtype controls, are insulin-resistant and develop diabetes. Transgenic mice expressing increased 11beta-HSD1 activity selectively in the liver do not increase their adipose tissue mass but develop mild insulin resistance and dyslipidemia.

\section{SURGICAL OR CHEMICAL MODELS OF OBEISTY}

\section{Lesion of the ventromedial hypothalamus (VMH lesion)}

One of the earliest models of induced obesity in rodents used rats with surgical lesions of the ventromedial/arcuate region of the mediobasal hypothalamus (VMH lesions) that resulted in hyperphagia, increased body weight and adiposity. While the precise causes of VMH-lesion induced obesity are still unclear, a change in the tone of the sympathetic (decrease) and parasympathetic (increase) nervous systems contributes to the syndrome; this is associated with reduced energy expenditure which may in part be due to reduced ambulatory activity and a disruption of the circadian rhythm in activity. Hyperphagia is probably due to the destruction of POMC neurons and possibly of neurons producing brain-derived neurotrophic factor (BDNF) in the hypothalamic arcuate nucleus (King, 1991; King, 2006; Penicaud et al., 1983).

VMH rats also have elevated circulating insulin and reduced glucagon. Both baseline and nutrient-stimulated insulin secretion are higher in VMH-lesioned rats. These hormonal changes are most likely due to a shift in autonomic tone that favors parasympathetic activity since removing the parasympathetic input to the pancreas where insulin is secreted keeps the VMH-lesioned animals from developing obesity (Cox and Powley, 1981).

\section{Lesion of the hypothalamic paraventricular nucleus (PVN lesion)}

Similar to VMH lesions, extensive lesions of the PVN also induce obesity. Obesity is mainly due to increased eating; energy expenditure and in particular ambulatory activity is not affected by PVN lesions, indicating that the mechanisms of the obesity phenotype of PVNlesioned rats differ from that of VMH lesions. Obesity in PVN-lesioned rats eventually results in insulin resistance and hyperinsulinemia (Bray and York, 1979; Sims and Lorden, 1986; Tokunaga et al., 1991).

\section{Lesion of the arcuate nucleus (ARC lesion)}

A selective surgical lesion of the ARC is difficult to perform due to the ARC's anatomical shape and location; most lesions performed so far encompassed the entire mediobasal hypothalamus, including the ventromedial area. As an alternative, the repeated administration of monosodium glutamate (MSG) to neonatal rats within the first 10 postnatal days has been used; this leads to the relatively selective destruction of ARC neurons projecting to the VMH and PVN. MSG-lesioned rats are hyperphagic and develop obesity with ensuing insulin resistance and hyperinsulinemia (Nemeroff et al., 1978). It is important to note that systemic MSG treatment also lesions neurons in the circumventricular organs due to their open blood-brain barrier. MSG lesions are therefore not restricted to the $\mathrm{ARC}$ and interpretation of results must take this into account.

ARC neurons can also be destroyed by local administration of gold thioglucose, resulting in a similar obesity phenotype (Bergen et al., 1998; Young, 1992; Young et al., 1994). A more selective lesion can also be obtained by the local administration of NPY-saporin (NPY-SAP) 
(Li et al., 2008). Due to the neurotoxin SAP, microinjection of NPY-SAP causes a loss of neurons carrying NPY receptors such as NPY and POMC/CART neurons. These lesions also produce hyperphagia and obesity but the origin of these phenotypic changes is still unclear; hyperphagia seems unrelated to the overexpression of orexigenic hypothalamic neuropeptides such as NPY, AgRP, MCH or the orexins.

\section{Ovariectomy}

Gonadectomy in females leads to an increase in body weight associated with an increase in eating. Ovariectomy (OVX) in female rats and mice has therefore been used as a model for the increased female obesity that occurs at menopause. Due to the lack of estradiol, OVX rats and mice do not exhibit the cyclic decrease in eating in estrus; this cyclic effect can be restored by estradiol replacement in OVX animals. Further, eating is also increased in OVX rats on other days of the cycle, indicating a tonic disinhibition due to the lack of estradiol. The mechanisms underlying the tonic increase in eating after OVX are not clear while the cyclic effect is probably caused by the (lack of) effect of estradiol on meal controllers such as CCK, GLP-1, glucagon and others (Asarian and Geary, 2002; Asarian and Geary, 2006; Asarian and Geary, 2007; Thammacharoen et al., 2008).

Interestingly, total adipose tissue mass is increased in OVX rats and in menopausal women; however, OVX causes a preferential deposition as subcutaneous fat whereas menopause leads to an increase in intraabdominal fat. Further, lean body mass is increased in OVX rats but decreased in menopause (Gloy et al., 2011). Importantly, OVX leads to an immediate transition from a normally cycling female to a non-cycling animal while the transition is more gradual in menopause.

\section{Ablation of brown adipose tissue (BAT)}

Brown adipose tissue (BAT) plays an important role in the control of energy expenditure; BAT expresses uncoupling protein 1 (UCP-1) which dissipates energy as heat. Transgenic mice with BAT ablation are markedly obese and have decreased energy expenditure (Hamann et al., 1996; Klaus et al., 1998). Ablation of BAT in these mice is achieved by expressing the diphtheria toxin A in UCP-1 expressing cells; this leads to ablation of approximately $70 \%$ of BAT. The obese phenotype is enhanced in mice on a high fat diet. With developing obesity, mice also become insulin resistant and eventually develop type 2 like diabetes mellitus.

\section{SEASONAL MODELS OF OBESITY}

\section{Syrian and Siberian hamsters}

Like other seasonal mammals, the body weight and body adiposity differ markedly across a yearly cycle in Syrian and Siberian hamsters (Bartness and Wade, 1985; Leitner and Bartness, 2011; Mercer and Tups, 2003; Tups, 2009). The ultimate trigger of these changes is the change in the photoperiod and consequently day length, and a resulting change in melatonin release. Even though being dependent on melatonin in both cases, the seasonal rhythmicity reveals interesting differences between the species because melatonin produces opposite effects on body weight in the two hamster species. The reproductive capacity decreases in both types of hamsters in short photoperiods; however, Syrian hamsters gain weight and Siberian hamsters lose weight under short-day conditions. The evolutionary strategy thus differs between the two species. The body weight changes are largely independent of altered energy intake in Syrian and in Siberian hamsters. In preparation for winter, Syrian hamsters store more energy as fat. Siberian hamsters, in contrast, reduce overall metabolism by reducing their metabolically active body mass; hence, total energy expenditure is reduced. 
At least some of these changes may be due to the altered sensitivity of hypothalamic circuits to leptin; however, it is unclear whether altered transport into the brain or altered signaling at the receptor or post-receptor level plays the primary role.

Many other animals exhibit seasonal fluctuations in body fat and associated metabolic parameters in anticipation of storing sufficient energy to last through the winter or else to make a long migration. For examples, marmots overeat and become quite obese in preparation for making it through the winter, and they have associated changes in plasma hormones and insulin sensitivity (Florant and Healy, 2011).

\section{OTHER MODELS OF OBESITY AND ASSOCIATED METABOLIC CHANGES}

\section{Lipodystrophy}

Obesity is strongly associated with insulin resistance, which itself is a major risk factor for the development of type 2 diabetes. Interestingly, the complete lack of fat tissue (lipodystrophy) leads to similar metabolic changes as severe obesity and is associated with insulin resistance. The common link seems to be the accumulation of excess fat in ectopic sites such as the liver and skeletal muscle; fat accumulation in the latter organs is associated with insulin resistance, type 2 diabetes and dyslipidemia.

Genetically modifed mice with a lack of adipose tissue are characterized by hyperphagia, hepatic steatosis, hypertriglyceridaemia, insulin resistance and type 2 diabetes. Due to the lack of functional adipose tissue, these mice are leptin deficient. Interestingly, leptin replacement at least partly restores the dysregulated metabolism in these mice (HuangDoran et al., 2010; Savage, 2009).

\section{GH-deficient dwarf rat}

The dwarf rat $(\mathrm{dw} / \mathrm{dw})$ results from a spontaneous mutation resulting in deficient growth hormone $(\mathrm{GH})$ synthesis and secretion. The rats are smaller but accumulate excessive amounts of body fat. This is most likely due to the lack of GH's effect as a major lipolytic hormone (Davies et al., 2007).

\section{Tubby}

The function of the tubby gene is only partly understood. Homozygous mutation of the tubby gene (tub) results in late-onset obesity but mice typically do not develop diabetes (Coleman and Eicher, 1990; Guan et al., 1998).

\section{References}

Asarian L, Geary N. Cyclic estradiol treatment normalizes body weight and restores physiological patterns of spontaneous feeding and sexual receptivity in ovariectomized rats. Horm Behav. 2002; 42:461-471. [PubMed: 12488112]

Asarian L, Geary N. Modulation of appetite by gonadal steroid hormones. Philos Trans R Soc Lond B Biol Sci. 2006; 361:1251-1263. [PubMed: 16815802]

Asarian L, Geary N. Estradiol enhances cholecystokinin-dependent lipid-induced satiation and activates estrogen receptor-alpha-expressing cells in the nucleus tractus solitarius of ovariectomized rats. Endocrinology. 2007; 148:5656-5666. [PubMed: 17823256]

Banks WA, Coon AB, Robinson SM, Moinuddin A, Shultz JM, Nakaoke R, Morley JE. Triglycerides induce leptinresistance at the blood-brain barrier. Diabetes. 2004; 53:1253-1260. [PubMed: 15111494]

Bartness TJ, Wade GN. Photoperiodic control of seasonal body weight cycles in hamsters. Neurosci Biobehav Rev. 1985; 9:599-612. [PubMed: 3909016] 
Bates SH, Kulkarni RN, Seifert M, Myers MG Jr. Roles for leptin receptor/STAT3-dependent and independent signals in the regulation of glucose homeostasis. Cell Metab. 2005; 1:169-178. [PubMed: 16054060]

Bates SH, Stearns WH, Dundon TA, Schubert M, Tso AW, Wang Y, Banks AS, Lavery HJ, Haq AK, Maratos-Flier E, Neel BG, Schwartz MW, Myers MG Jr. STAT3 signalling is required for leptin regulation of energy balance but not reproduction. Nature. 2003; 421:856-859. [PubMed: 12594516]

Becskei C, Lutz TA, Riediger T. Blunted fasting-induced hypothalamic activation and refeeding hyperphagia in late-onset obesity. Neuroendocrinology. 2009; 90:371-382. [PubMed: 19844081]

Becskei C, Lutz TA, Riediger T. Reduced fasting-induced activation of hypothalamic arcuate neurons is associated with hyperleptinemia and increased leptin sensitivity in obese mice. Am J Physiol Regul Integr Comp Physiol. 2010; 299:R632-641. [PubMed: 20538900]

Benoit SC, Kemp CJ, Elias CF, Abplanalp W, Herman JP, Migrenne S, Lefevre AL, CrucianiGuglielmacci C, Magnan C, Yu F, Niswender K, Irani BG, Holland WL, Clegg DJ. Palmitic acid mediates hypothalamic insulin resistance by altering PKC-theta subcellular localization in rodents. J Clin Invest. 2009; 119:2577-2589. [PubMed: 19726875]

Bergen HT, Mizuno TM, Taylor J, Mobbs CV. Hyperphagia and weight gain after gold-thioglucose: relation to hypothalamic neuropeptide $\mathrm{Y}$ and proopiomelanocortin. Endocrinology. 1998; 139:4483-4488. [PubMed: 9794456]

Bray GA. The Zucker-fatty rat: a review. Fed Proc. 1977; 36:148-153. [PubMed: 320051]

Bray GA, York DA. Hypothalamic and genetic obesity in experimental animals: an autonomic and endocrine hypothesis. Physiol Rev. 1979; 59:719-809. [PubMed: 379887]

Bruning JC, Gautam D, Burks DJ, Gillette J, Schubert M, Orban PC, Klein R, Krone W, MullerWieland D, Kahn CR. Role of brain insulin receptor in control of body weight and reproduction. Science. 2000; 289:2122-2125. [PubMed: 11000114]

Bures EJ, Courchesne PL, Douglass J, Chen K, Davis MT, Jones MD, McGinley MD, Robinson JH, Spahr CS, Sun J, Wahl RC, Patterson SD. Identification of incompletely processed potential carboxypeptidase E substrates from CpEfat/CpEfat mice. Proteomics. 2001; 1:79-92. [PubMed: 11680901]

Butler AA, Kesterson RA, Khong K, Cullen MJ, Pelleymounter MA, Dekoning J, Baetscher M, Cone RD. A unique metabolic syndrome causes obesity in the melanocortin-3 receptor-deficient mouse. Endocrinology. 2000; 141:3518-3521. [PubMed: 10965927]

Campfield LA, Smith FJ, Guisez Y, Devos R, Burn P. Recombinant mouse OB protein: evidence for a peripheral signal linking adiposity and central neural networks. Science. 1995; 269:546-549. [PubMed: 7624778]

Challis BG, Coll AP, Yeo GS, Pinnock SB, Dickson SL, Thresher RR, Dixon J, Zahn D, Rochford JJ, White A, Oliver RL, Millington G, Aparicio SA, Colledge WH, Russ AP, Carlton MB, O'Rahilly $\mathrm{S}$. Mice lacking pro-opiomelanocortin are sensitive to high-fat feeding but respond normally to the acute anorectic effects of peptide-YY(3-36). Proc Natl Acad Sci U S A. 2004; 101:4695-4700. [PubMed: 15070780]

Chen AS, Marsh DJ, Trumbauer ME, Frazier EG, Guan XM, Yu H, Rosenblum CI, Vongs A, Feng Y, Cao L, Metzger JM, Strack AM, Camacho RE, Mellin TN, Nunes CN, Min W, Fisher J, GopalTruter S, MacIntyre DE, Chen HY, Van der Ploeg LH. Inactivation of the mouse melanocortin-3 receptor results in increased fat mass and reduced lean body mass. Nat Genet. 2000; 26:97-102. [PubMed: 10973258]

Chua SC Jr, Chung WK, Wu-Peng XS, Zhang Y, Liu SM, Tartaglia L, Leibel RL. Phenotypes of mouse diabetes and rat fatty due to mutations in the OB (leptin) receptor. Science. 1996; 271 :994996. [PubMed: 8584938]

Clegg DJ, Gotoh K, Kemp C, Wortman MD, Benoit SC, Brown LM, D’Alessio D, Tso P, Seeley RJ, Woods SC. Consumption of a high-fat diet induces central insulin resistance independent of adiposity. Physiol Behav. 2011; 103:10-16. [PubMed: 21241723]

Coleman DL. Obese and diabetes: two mutant genes causing diabetes-obesity syndromes in mice. Diabetologia. 1978; 14:141-148. [PubMed: 350680] 
Coleman DL, Eicher EM. Fat (fat) and tubby (tub): two autosomal recessive mutations causing obesity syndromes in the mouse. J Hered. 1990; 81:424-427. [PubMed: 2250094]

Corander MP, Rimmington D, Challis BG, O'Rahilly S, Coll AP. Loss of agouti-related peptide does not significantly impact the phenotype of murine POMC deficiency. Endocrinology. 2011; 152:1819-1828. [PubMed: 21363936]

Cox JE, Powley TL. Prior vagotomy blocks VMH obesity in pair-fed rats. Am J Physiol. 1981; 240:E573-583. [PubMed: 7235009]

Crouse JA, Elliott GE, Burgess TL, Chiu L, Bennett L, Moore J, Nicolson M, Pacifici RE. Altered cell surface expression and signaling of leptin receptors containing the fatty mutation. J Biol Chem. 1998; 273:18365-18373. [PubMed: 9660803]

da Silva BA, Bjorbaek C, Uotani S, Flier JS. Functional properties of leptin receptor isoforms containing the gln--> pro extracellular domain mutation of the fatty rat. Endocrinology. 1998; 139:3681-3690. [PubMed: 9724018]

Davies JS, Gevers EF, Stevenson AE, Coschigano KT, El-Kasti MM, Bull MJ, Elford C, Evans BA, Kopchick JJ, Wells T. Adiposity profile in the dwarf rat: an unusually lean model of profound growth hormone deficiency. Am J Physiol Endocrinol Metab. 2007; 292:E1483-1494. [PubMed: 17264226]

Faust IM, Johnson PR, Hirsch J. Long-term effects of early nutritional experience on the development of obesity in the rat. J Nutr. 1980; 110:2027-2034. [PubMed: 7420206]

Figlewicz DP, Ikeda H, Hunt TR, Stein LJ, Dorsa DM, Woods SC, Porte D Jr. Brain insulin binding is decreased in Wistar Kyoto rats carrying the 'fa' gene. Peptides. 1986; 7:61-65. [PubMed: 3714533]

Florant GL, Healy JE. The regulation of food intake in mammalian hibernators: a review. J Comp Physiol B. 2011

Friedman JM. Leptin, leptin receptors and the control of body weight. Eur J Med Res. 1997; 2:7-13. [PubMed: 9049588]

Friedman JM. Leptin, leptin receptors, and the control of body weight. Nutr Rev. 1998; 56:s38-46. discussion s54-75. [PubMed: 9564176]

Gloy V, Langhans W, Hillebrand JJ, Geary N, Asarian L. Ovariectomy and overeating palatable, energy-dense food increase subcutaneous adipose tissue more than intra-abdominal adipose tissue in rats. Biol Sex Differ. 2011; 2:6. [PubMed: 21569336]

Graham M, Shutter JR, Sarmiento U, Sarosi I, Stark KL. Overexpression of Agrt leads to obesity in transgenic mice. Nat Genet. 1997; 17:273-274. [PubMed: 9354787]

Guan XM, Yu H, Van der Ploeg LH. Evidence of altered hypothalamic pro-opiomelanocortin/ neuropeptide Y mRNA expression in tubby mice. Brain Res Mol Brain Res. 1998; 59:273-279. [PubMed: 9729427]

Halaas JL, Gajiwala KS, Maffei M, Cohen SL, Chait BT, Rabinowitz D, Lallone RL, Burley SK, Friedman JM. Weight-reducing effects of the plasma protein encoded by the obese gene. Science. 1995; 269:543-546. [PubMed: 7624777]

Hamann A, Flier JS, Lowell BB. Decreased brown fat markedly enhances susceptibility to dietinduced obesity, diabetes, and hyperlipidemia. Endocrinology. 1996; 137:21-29. [PubMed: 8536614]

Hansen BC, Ortmeyer HK, Bodkin NL. Prevention of obesity in middle-aged monkeys: food intake during body weight clamp. Obes Res. 1995; 3(Suppl 2):199s-204s. [PubMed: 8581777]

Hariri N, Thibault L. High-fat diet-induced obesity in animal models. Nutr Res Rev. 2010; 23:270299. [PubMed: 20977819]

Heisler LK, Tecott LH. Knockout Corner: Neurobehavioural consequences of a serotonin 5-HT(2C) receptor gene mutation. Int J Neuropsychopharmacol. 1999; 2:67-69. [PubMed: 11281972]

Huang-Doran I, Sleigh A, Rochford JJ, O'Rahilly S, Savage DB. Lipodystrophy: metabolic insights from a rare disorder. J Endocrinol. 2010; 207:245-255. [PubMed: 20870709]

Huszar D, Lynch CA, Fairchild-Huntress V, Dunmore JH, Fang Q, Berkemeier LR, Gu W, Kesterson RA, Boston BA, Cone RD, Smith FJ, Campfield LA, Burn P, Lee F. Targeted disruption of the melanocortin-4 receptor results in obesity in mice. Cell. 1997; 88:131-141. [PubMed: 9019399] 
Ikeda H, Shino A, Matsuo T, Iwatsuka H, Suzuoki Z. A new genetically obese-hyperglycemic rat (Wistar fatty). Diabetes. 1981; 30:1045-1050. [PubMed: 7030830]

Joost HG. The genetic basis of obesity and type 2 diabetes: lessons from the new zealand obese mouse, a polygenic model of the metabolic syndrome. Results Probl Cell Differ. 2010; 52:1-11. [PubMed: 20865367]

Kaiyala KJ, Schwartz MW. Toward a more complete (and less controversial) understanding of energy expenditure and its role in obesity pathogenesis. Diabetes. 2011; 60:17-23. [PubMed: 21193735]

Kawano K, Hirashima T, Mori S, Saitoh Y, Kurosumi M, Natori T. Spontaneous long-term hyperglycemic rat with diabetic complications. Otsuka Long-Evans Tokushima Fatty (OLETF) strain. Diabetes. 1992; 41:1422-1428. [PubMed: 1397718]

King BM. Ventromedial hypothalamic obesity: a reexamination of the irritative hypothesis. Neurosci Biobehav Rev. 1991; 15:341-347. [PubMed: 1956603]

King BM. The rise, fall, and resurrection of the ventromedial hypothalamus in the regulation of feeding behavior and body weight. Physiol Behav. 2006; 87:221-244. [PubMed: 16412483]

Klaus S, Munzberg H, Truloff C, Heldmaier G. Physiology of transgenic mice with brown fat ablation: obesity is due to lowered body temperature. Am J Physiol. 1998; 274:R287-293. [PubMed: 9486283]

Klebig ML, Wilkinson JE, Geisler JG, Woychik RP. Ectopic expression of the agouti gene in transgenic mice causes obesity, features of type II diabetes, and yellow fur. Proc Natl Acad Sci U S A. 1995; 92:4728-4732. [PubMed: 7761391]

Kushi A, Sasai H, Koizumi H, Takeda N, Yokoyama M, Nakamura M. Obesity and mild hyperinsulinemia found in neuropeptide Y-Y1 receptor-deficient mice. Proc Natl Acad Sci U S A. 1998; 95:15659-15664. [PubMed: 9861026]

Leibel RL. Molecular physiology of weight regulation in mice and humans. Int J Obes (Lond). 2008; 32(Suppl 7):S98-108. [PubMed: 19136999]

Leitner C, Bartness TJ. An intact dorsomedial hypothalamic nucleus, but not the subzona incerta or reuniens nucleus, is necessary for short-day melatonin signal-induced responses in Siberian hamsters. Neuroendocrinology. 2011; 93:29-39. [PubMed: 20847551]

Levin BE, Dunn-Meynell AA. Defense of body weight against chronic caloric restriction in obesityprone and -resistant rats. Am J Physiol Regul Integr Comp Physiol. 2000; 278:R231-237. [PubMed: 10644644]

Levin BE, Dunn-Meynell AA. Defense of body weight depends on dietary composition and palatability in rats with diet-induced obesity. Am J Physiol Regul Integr Comp Physiol. 2002; 282:R46-54. [PubMed: 11742822]

Levin BE, Dunn-Meynell AA, Balkan B, Keesey RE. Selective breeding for diet-induced obesity and resistance in Sprague-Dawley rats. Am J Physiol. 1997; 273:R725-730. [PubMed: 9277561]

Levin BE, Govek E. Gestational obesity accentuates obesity in obesity-prone progeny. Am J Physiol. 1998; 275:R1374-1379. [PubMed: 9756571]

Levin BE, Triscari J, Sullivan AC. The effect of diet and chronic obesity on brain catecholamine turnover in the rat. Pharmacol Biochem Behav. 1986; 24:299-304. [PubMed: 3952118]

Li AJ, Dinh TT, Ritter S. Hyperphagia and obesity produced by arcuate injection of NPY-saporin do not require upregulation of lateral hypothalamic orexigenic peptide genes. Peptides. 2008; 29:1732-1739. [PubMed: 18577407]

Lo CM, King A, Samuelson LC, Kindel TL, Rider T, Jandacek RJ, Raybould HE, Woods SC, Tso P. Cholecystokinin knockout mice are resistant to high-fat diet-induced obesity. Gastroenterology. 2010

Ludwig DS, Tritos NA, Mastaitis JW, Kulkarni R, Kokkotou E, Elmquist J, Lowell B, Flier JS, Maratos-Flier E. Melanin-concentrating hormone overexpression in transgenic mice leads to obesity and insulin resistance. J Clin Invest. 2001; 107:379-386. [PubMed: 11160162]

Man TY, Michailidou Z, Gokcel A, Ramage L, Chapman KE, Kenyon CJ, Seckl JR, Morton NM. Dietary manipulation reveals an unexpected inverse relationship between fat mass and adipose 11 beta-hydroxysteroid dehydrogenase type 1. Am J Physiol Endocrinol Metab. 2011; 300:E10761084. [PubMed: 21406612] 
Mayer J, Bates MW, Dickie MM. Hereditary diabetes in genetically obese mice. Science. 1951; 113:746-747. [PubMed: 14854871]

Mercer JG, Tups A. Neuropeptides and anticipatory changes in behaviour and physiology: seasonal body weight regulation in the Siberian hamster. Eur J Pharmacol. 2003; 480:43-50. [PubMed: 14623349]

Michaud EJ, Bultman SJ, Klebig ML, van Vugt MJ, Stubbs LJ, Russell LB, Woychik RP. A molecular model for the genetic and phenotypic characteristics of the mouse lethal yellow (Ay) mutation. Proc Natl Acad Sci U S A. 1994; 91:2562-2566. [PubMed: 8146154]

Michel C, Dunn-Meynell A, Levin BE. Reduced brain CRH and GR mRNA expression precedes obesity in juvenile rats bred for diet-induced obesity. Behav Brain Res. 2004; 154:511-517. [PubMed: 15313040]

Moran TH. Unraveling the obesity of OLETF rats. Physiol Behav. 2008; 94:71-78. [PubMed: 18190934]

Moran TH, Bi S. Hyperphagia and obesity in OLETF rats lacking CCK-1 receptors. Philos Trans R Soc Lond B Biol Sci. 2006; 361:1211-1218. [PubMed: 16815799]

Morgan HD, Sutherland HG, Martin DI, Whitelaw E. Epigenetic inheritance at the agouti locus in the mouse. Nat Genet. 1999; 23:314-318. [PubMed: 10545949]

Morris MJ, Velkoska E, Cole TJ. Central and peripheral contributions to obesity-associated hypertension: impact of early overnourishment. Exp Physiol. 2005; 90:697-702. [PubMed: 16105938]

Mul JD, van Boxtel R, Bergen DJ, Brans MA, Brakkee JH, Toonen PW, Garner KM, Adan RA, Cuppen E. Melanocortin Receptor 4 Deficiency Affects Body Weight Regulation, Grooming Behavior, and Substrate Preference in the Rat. Obesity (Silver Spring). 2011

Naggert JK, Fricker LD, Varlamov O, Nishina PM, Rouille Y, Steiner DF, Carroll RJ, Paigen BJ, Leiter EH. Hyperproinsulinaemia in obese fat/fat mice associated with a carboxypeptidase E mutation which reduces enzyme activity. Nat Genet. 1995; 10:135-142. [PubMed: 7663508]

Naveilhan P, Hassani H, Canals JM, Ekstrand AJ, Larefalk A, Chhajlani V, Arenas E, Gedda K, Svensson L, Thoren P, Ernfors P. Normal feeding behavior, body weight and leptin response require the neuropeptide Y Y2 receptor. Nat Med. 1999; 5:1188-1193. [PubMed: 10502824]

Nemeroff CB, Lipton MA, Kizer JS. Models of neuroendocrine regulation: use of monosodium glutamate as an investigational tool. Dev Neurosci. 1978; 1:102-109. [PubMed: 39735]

O'Rahilly S. Human genetics illuminates the paths to metabolic disease. Nature. 2009; 462:307-314. [PubMed: 19924209]

Ohki-Hamazaki H, Watase K, Yamamoto K, Ogura H, Yamano M, Yamada K, Maeno H, Imaki J, Kikuyama S, Wada E, Wada K. Mice lacking bombesin receptor subtype-3 develop metabolic defects and obesity. Nature. 1997; 390:165-169. [PubMed: 9367152]

Paterson JM, Morton NM, Fievet C, Kenyon CJ, Holmes MC, Staels B, Seckl JR, Mullins JJ. Metabolic syndrome without obesity: Hepatic overexpression of 11 beta-hydroxysteroid dehydrogenase type 1 in transgenic mice. Proc Natl Acad Sci U S A. 2004; 101:7088-7093. [PubMed: 15118095]

Patterson CM, Bouret SG, Park S, Irani BG, Dunn-Meynell AA, Levin BE. Large litter rearing enhances leptin sensitivity and protects selectively bred diet-induced obese rats from becoming obese. Endocrinology. 2010; 151:4270-4279. [PubMed: 20668022]

Pelleymounter MA, Cullen MJ, Baker MB, Hecht R, Winters D, Boone T, Collins F. Effects of the obese gene product on body weight regulation in ob/ob mice. Science. 1995; 269:540-543. [PubMed: 7624776]

Penicaud L, Larue-Achagiotis C, Le Magnen J. Endocrine basis for weight gain after fasting or VMH lesion in rats. Am J Physiol. 1983; 245:E246-252. [PubMed: 6351633]

Perez C, Fanizza LJ, Sclafani A. Flavor preferences conditioned by intragastric nutrient infusions in rats fed chow or a cafeteria diet. Appetite. 1999; 32:155-170. [PubMed: 9989925]

Rogers PJ, Blundell JE. Meal patterns and food selection during the development of obesity in rats fed a cafeteria diet. Neurosci Biobehav Rev. 1984; 8:441-453. [PubMed: 6542632]

Rothwell NJ, Stock MJ. Combined effects of cafeteria and tube-feeding on energy balance in the rat. Proc Nutr Soc. 1979; 38:5A. 
Savage DB. Mouse models of inherited lipodystrophy. Dis Model Mech. 2009; 2:554-562. [PubMed: 19892886]

Schmidt I, Fritz A, Scholch C, Schneider D, Simon E, Plagemann A. The effect of leptin treatment on the development of obesity in overfed suckling Wistar rats. Int J Obes Relat Metab Disord. 2001; 25:1168-1174. [PubMed: 11477501]

Schwartz MW, Woods SC, Porte D Jr, Seeley RJ, Baskin DG. Central nervous system control of food intake. Nature. 2000; 404:661-671. [PubMed: 10766253]

Schwartz MW, Woods SC, Seeley RJ, Barsh GS, Baskin DG, Leibel RL. Is the energy homeostasis system inherently biased toward weight gain? Diabetes. 2003; 52:232-238. [PubMed: 12540591]

Schwartz SM, Kemnitz JW, Howard CF Jr. Obesity in free-ranging rhesus macaques. Int J Obes Relat Metab Disord. 1993; 17:1-9. [PubMed: 8383634]

Shepherd PR, Gnudi L, Tozzo E, Yang H, Leach F, Kahn BB. Adipose cell hyperplasia and enhancedglucose disposal in transgenic mice overexpressing GLUT4 selectively in adipose tissue. J Biol Chem. 1993; 268:22243-22246. [PubMed: 8226728]

Sims JS, Lorden JF. Effect of paraventricular nucleus lesions on body weight, food intake and insulin levels. Behav Brain Res. 1986; 22:265-281. [PubMed: 3098259]

Stenzel-Poore MP, Cameron VA, Vaughan J, Sawchenko PE, Vale W. Development of Cushing's syndrome in corticotropin-releasing factor transgenic mice. Endocrinology. 1992; 130:3378-3386. [PubMed: 1597149]

Sullivan EL, Grayson B, Takahashi D, Robertson N, Maier A, Bethea CL, Smith MS, Coleman K, Grove KL. Chronic consumption of a high-fat diet during pregnancy causes perturbations in the serotonergic system and increased anxiety-like behavior in nonhuman primate offspring. J Neurosci. 2010a; 30:3826-3830. [PubMed: 20220017]

Sullivan EL, Smith MS, Grove KL. Perinatal Exposure to High-Fat Diet Programs Energy Balance, Metabolism and Behavior in Adulthood. Neuroendocrinology. 2010b

Susulic VS, Frederich RC, Lawitts J, Tozzo E, Kahn BB, Harper ME, Himms-Hagen J, Flier JS, Lowell BB. Targeted disruption of the beta 3-adrenergic receptor gene. J Biol Chem. 1995; 270:29483-29492. [PubMed: 7493988]

Takaya K, Ogawa Y, Hiraoka J, Hosoda K, Yamori Y, Nakao K, Koletsky RJ. Nonsense mutation of leptin receptor in the obese spontaneously hypertensive Koletsky rat. Nat Genet. 1996; 14:130131. [PubMed: 8841178]

Tamashiro KL, Terrillion CE, Hyun J, Koenig JI, Moran TH. Prenatal stress or high-fat diet increases susceptibility to diet-induced obesity in rat offspring. Diabetes. 2009; 58:1116-1125. [PubMed: 19188431]

Tecott LH, Sun LM, Akana SF, Strack AM, Lowenstein DH, Dallman MF, Julius D. Eating disorder and epilepsy in mice lacking 5-HT2c serotonin receptors. Nature. 1995; 374:542-546. [PubMed: 7700379]

Thammacharoen S, Lutz TA, Geary N, Asarian L. Hindbrain administration of estradiol inhibits feeding and activates estrogen receptor-alpha-expressing cells in the nucleus tractus solitarius of ovariectomized rats. Endocrinology. 2008; 149:1609-1617. [PubMed: 18096668]

Thorburn AW, Baldwin ME, Rosella G, Zajac JD, Fabris S, Song S, Proietto J. Features of syndrome $\mathrm{X}$ develop in transgenic rats expressing a non-insulin responsive phosphoenolpyruvate carboxykinase gene. Diabetologia. 1999; 42:419-426. [PubMed: 10230645]

Tokunaga K, Matsuzawa Y, Fujioka S, Kobatake T, Keno Y, Odaka H, Matsuo T, Tarui S. PVNlesioned obese rats maintain ambulatory activity and its circadian rhythm. Brain Res Bull. 1991; 26:393-396. [PubMed: 2049605]

Tups A. Physiological models of leptin resistance. J Neuroendocrinol. 2009; 21:961-971. [PubMed: 19732287]

West DB, Diaz J, Roddy S, Woods SC. Long-term effects on adiposity after preweaning nutritional manipulations in the gastrostomy-reared rat. J Nutr. 1987; 117:1259-1264. [PubMed: 3112335]

West DB, Diaz J, Woods SC. Infant gastrostomy and chronic formula infusion as a technique to overfeed and accelerate weight gain of neonatal rats. J Nutr. 1982; 112:1339-1343. [PubMed: 6808095] 
Willett WC, Leibel RL. Dietary fat is not a major determinant of body fat. Am J Med. 2002; 113(Suppl 9B):47S-59S. [PubMed: 12566139]

Wolff GL, Kodell RL, Moore SR, Cooney CA. Maternal epigenetics and methyl supplements affect agouti gene expression in Avy/a mice. FASEB J. 1998; 12:949-957. [PubMed: 9707167]

Woods SC. The eating paradox: how we tolerate food. Psychol Rev. 1991; 98:488-505. [PubMed: 1961770]

Woods SC. The control of food intake: behavioral versus molecular perspectives. Cell Metab. 2009; 9:489-498. [PubMed: 19490904]

Woods SC, D’Alessio DA, Tso P, Rushing PA, Clegg DJ, Benoit SC, Gotoh K, Liu M, Seeley RJ. Consumption of a high-fat diet alters the homeostatic regulation of energy balance. Physiol Behav. 2004; 83:573-578. [PubMed: 15621062]

Wu-Peng XS, Chua SC Jr, Okada N, Liu SM, Nicolson M, Leibel RL. Phenotype of the obese Koletsky (f) rat due to Tyr763Stop mutation in theextracellular domain of the leptin receptor (Lepr): evidence for deficient plasma-to-CSF transport of leptin in both the Zucker and Koletsky obese rat. Diabetes. 1997; 46:513-518. [PubMed: 9032111]

Yaswen L, Diehl N, Brennan MB, Hochgeschwender U. Obesity in the mouse model of proopiomelanocortin deficiency responds to peripheral melanocortin. Nat Med. 1999; 5:1066-1070. [PubMed: 10470087]

Yen TT, Gill AM, Frigeri LG, Barsh GS, Wolff GL. Obesity, diabetes, and neoplasia in yellow A(vy)/ - mice: ectopic expressionof the agouti gene. FASEB J. 1994; 8:479-488. [PubMed: 8181666]

Young JK. Hypothalamic lesions increase neuronal immunoreactivity for neuropeptide Y. Brain Res Bull. 1992; 29:375-380. [PubMed: 1393610]

Young JK, McKenzie JC, Brady LS, Herkenham M. Hypothalamic lesions increase levels of neuropeptide Y mRNA in the arcuate nucleus of mice. Neurosci Lett. 1994; 165:13-17. [PubMed: 8015714]

Zhang Y, Proenca R, Maffei M, Barone M, Leopold L, Friedman JM. Positional cloning of the mouse obese gene and its human homologue. Nature. 1994; 372:425-432. [PubMed: 7984236]

Zierath JR, Ryder JW, Doebber T, Woods J, Wu M, Ventre J, Li Z, McCrary C, Berger J, Zhang B, Moller DE. Role of skeletal muscle in thiazolidinedione insulin sensitizer (PPARgamma agonist) action. Endocrinology. 1998; 139:5034-5041. [PubMed: 9832442] 


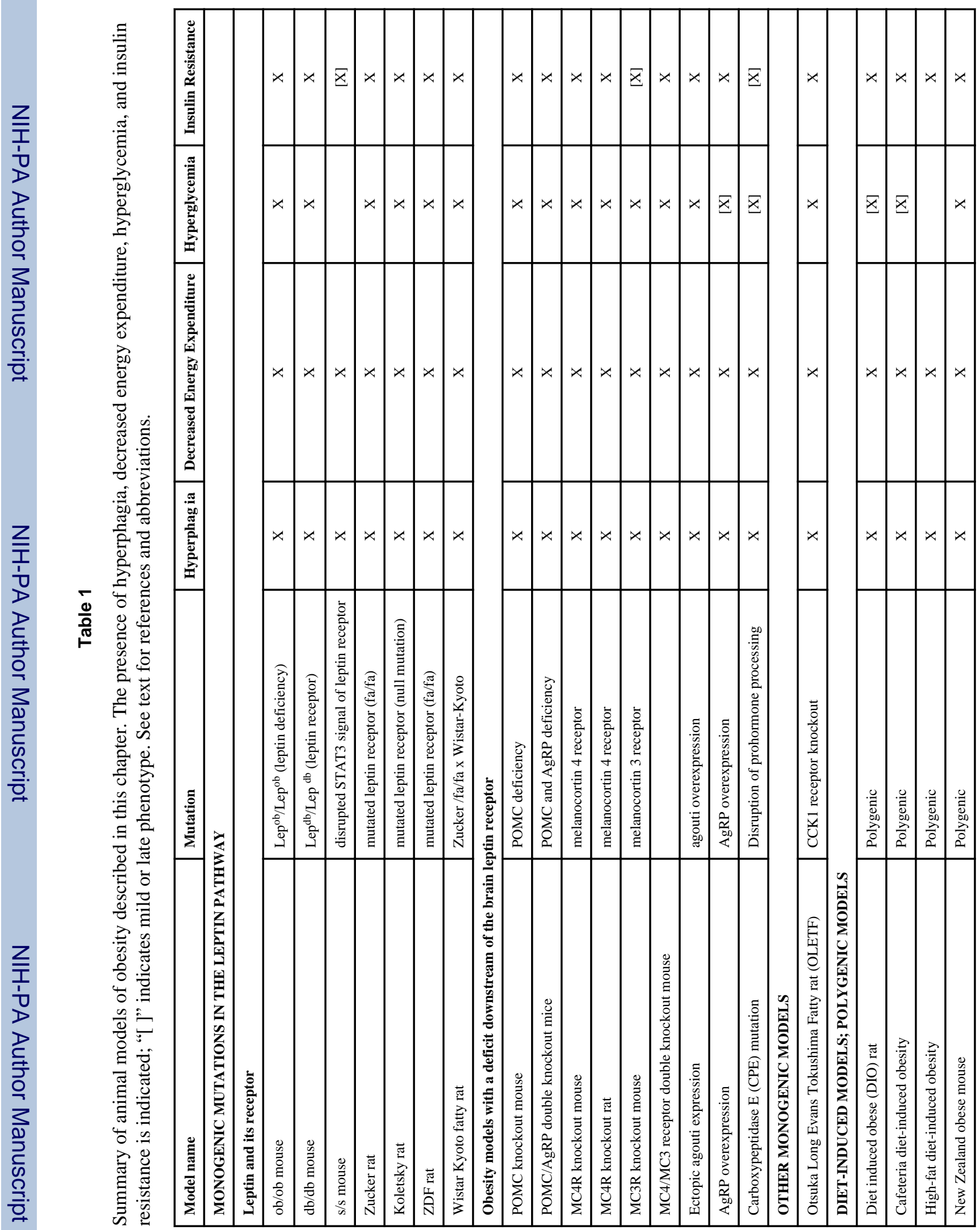




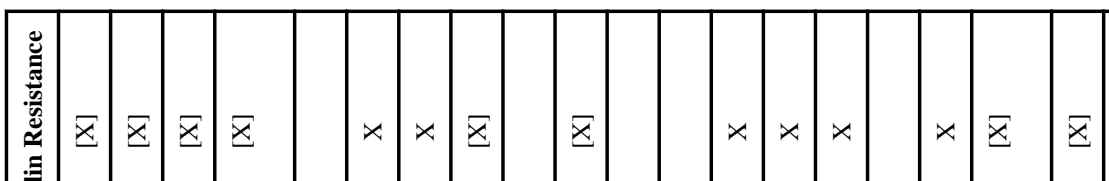

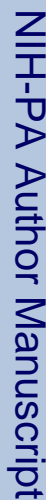

Z

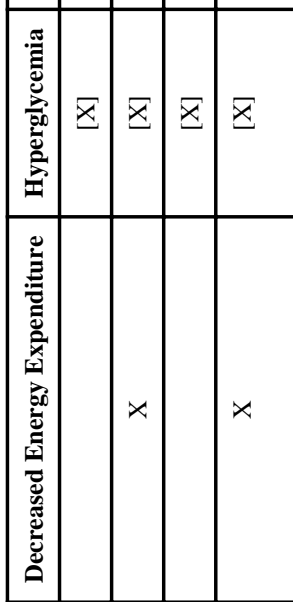

$\bar{x} x$

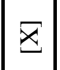

$x \times x \quad x \quad \bar{x} \quad \bar{\Xi}$

ఔ
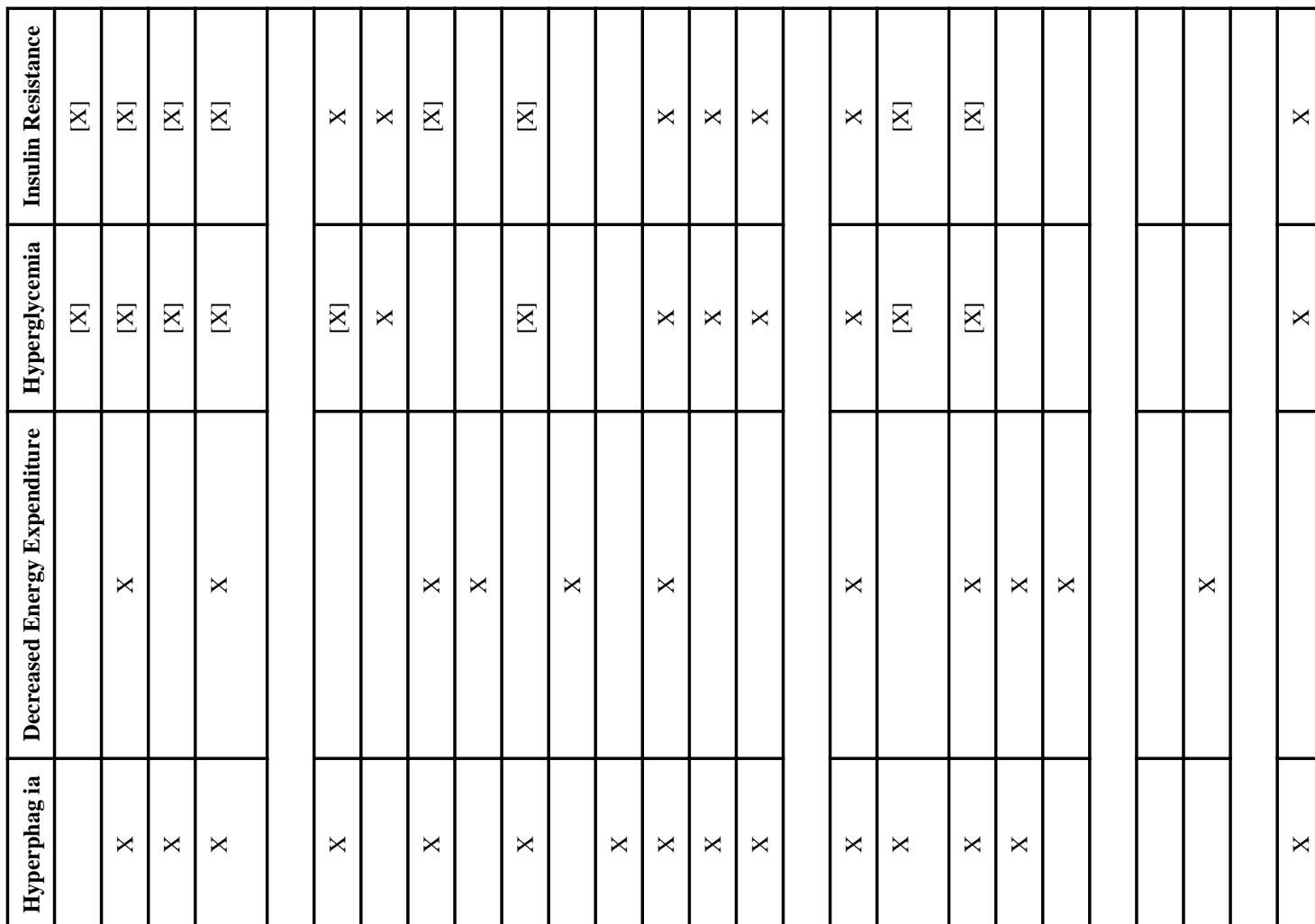

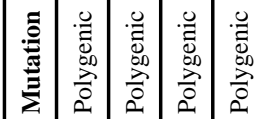
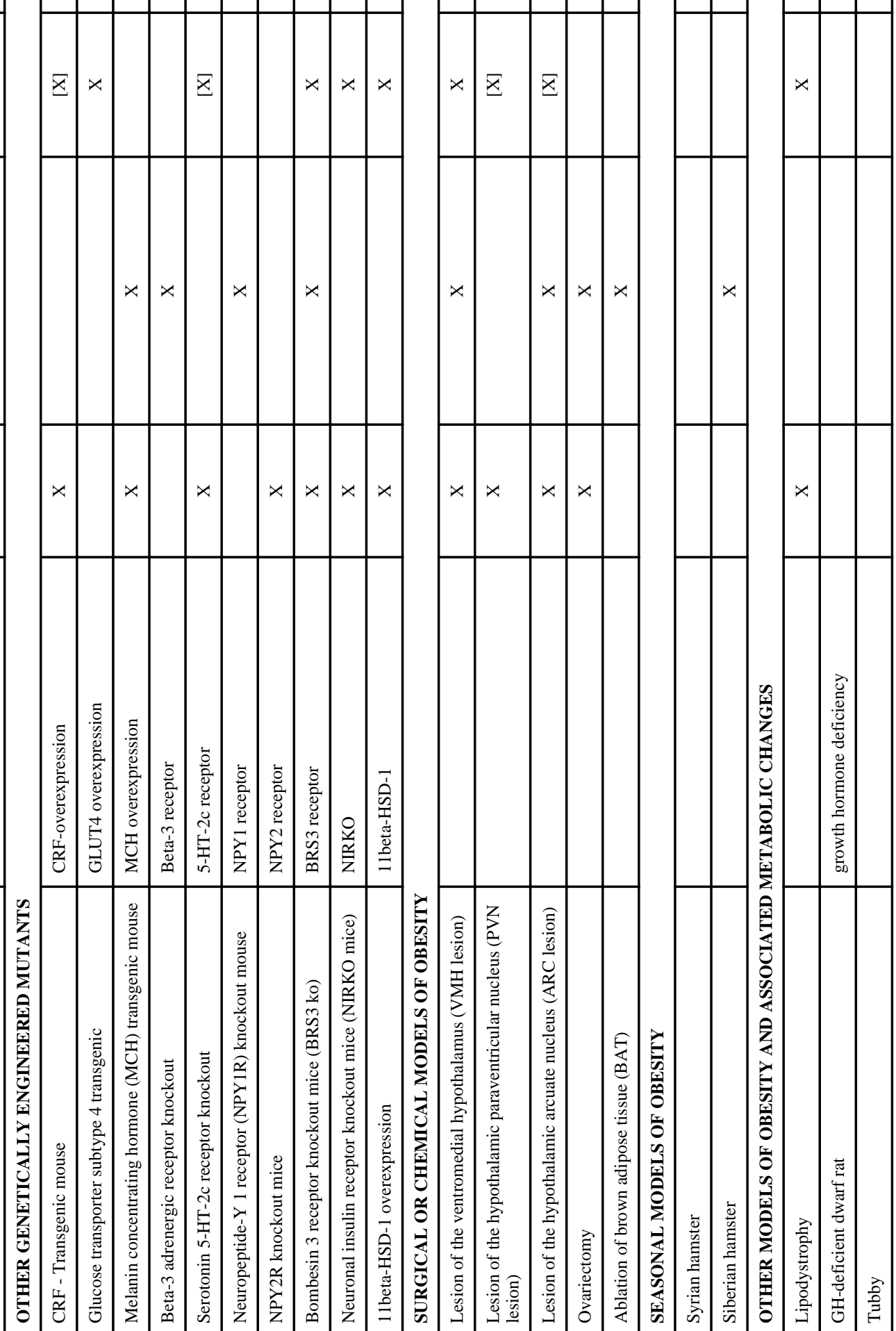

$x$

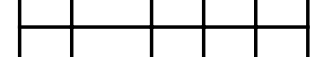

$x$

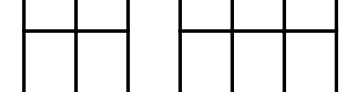

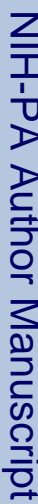

